\title{
Editorial
}

\section{Citius, altius, fortius, suspenso}

\author{
Jean-Louis Peytavin
}

O relatório da comissáo da World Anti Doping Agency (WADA) provocou um terremoto no mundo do atletismo no dia de seu lançamento público, em 9 de novembro de 2015 [1]. Este relatório, dirigido pele canadense Richard Pound, estabelece claramente a responsabilidade de inúmeros atletas, dirigentes, médicos e treinadores da Rússia no maior escândalo de doping de todos os tempos, onde se encontra todos os elementos não só do doping, mas também da corrupção e da razão de estado, como no velho tempo da guerra fria.

A WADA atingiu o alvo o mais fácil, visto que muitas acusações bem documentadas já eram relatadas por jornalistas alemães e ingleses, justamente sobre o caso russo. O relatório já provocou uma cascata de demissões nas instâncias russas e internacionais, começando pelo antigo presidente da Federação Internacional de Atletismo (IAAF), o senegalês Lamine Diack, que era até hoje membro honorário do Comitê Olímpico Internacional.

Nos próximos episódios desta novela, que vai fazer o novo presidente da IAAF, o inglês Sebastian Coe? A Rússia, apesar de reclamar da perseguição política, vai ter que fazer uma grande faxina se quiser participar dos Jogos do Rio de Janeiro, e Sebastian Coe estabeleceu prazos. Mas a Rússia não é isolada, e o inquérito no mundo do esporte, dirigido pela Interpol, vai descobrir que o doping não é uma especialidade russa, nem do atletismo. Após o ciclismo e o atletismo, nas suas diversas modalidades, estamos esperando a vez da natação e do futebol, e as explicaçôes de vários países. É uma situaçáo de emergência: sem mudança imediata, a cidade olímpica do Rio de Janeiro vai ser vazia, ou virar um supermercado de drogas. Faster, higher, stronger, suspended (citius, altius, fortius, suspenso)? pergunta a imprensa americana. Isso é um bom resumo da situação atual.

\section{Referências}

World Anti Doping Agency (WADA). Relatório da comissão independente. Disponível em: https:// www.wada-ama.org/en/resources/world-anti-doping-program/independent-commission-report-1; 9 nov 2015. 